\title{
EDUCAÇÃO INFANTIL: A ORGANIZAÇÃO CURRICULAR E A METODOLOGIA SUGERIDA COM OS CAMPOS DE EXPERIÊNCIAS DA BASE NACIONAL COMUM CURRICULAR
}

\author{
Ana Cleide da Silva ${ }^{1}$ \\ Diógenes José Gusmão Coutinho²
}

\begin{abstract}
Resumo: O presente artigo traz uma abordagem reflexiva da organização curricular que se tem hoje para Educação Infantil com a promulgação da BNCC e a trajetória curricular nas últimas décadas por meio de revisões bibliográficas nas legislações brasileiras, nas bibliografias como livros, artigos científicos, revistas e documentos eletrônicos contemporâneos e tradicionais na busca e alocação de conhecimento sobre a educação infantil, sua importância e sua trajetória tudo discorrido por um referencial teórico que conceitua de forma breve o panorama legislativo com as diretrizes e referenciais curriculares para educação infantil a própria Base Comum Curricular para Educação Infantil onde o referido documento reforça a organização curricular e normatiza as atividades nesta etapa com pilares firmados em Direitos de Aprendizagens e com premissas em seis bases que são: Conviver, Brincar, Participar, Explorar, Expressar e Conhecer-se, a serem desenvolvidas em um contexto concreto de experimentos que propicie as crianças a desenvolver-se por meio do qual a BNCC sabiamente apresenta como "campos de experiências" e por fim a metodologia ativa que no que lhe concerne não é atual surgiu com o rompimento da pedagogia tradicional depois de muitas lutas dos seus precursores através de muita dedicação em estudos e afinco, conseguiu se firmar por sua eficácia comprovada na vida escolar e pessoal dos indivíduos quando fora defendida por vários revolucionários da educação mundial, aqui trazemos o Jean Piaget (1896-1980) que considera que o conhecimento dá-se de forma interacionista dos indivíduos com os objetos do conhecimento e se respeitando cada fase do desenvolvimento orgânico da vida do ser, principalmente no que cerne o desenvolvimento cognitivo da criança e para que isso aconteça Piaget enfatiza que o sistema educacional deve criar método que viabilizem essa interação intencional que estimulem essa construção, considera-se que a trajetória curricular tem agregado valores reais para a construção histórica social da Educação Infantil.
\end{abstract}

Palavras-Chave: Desenvolvimento Infantil. Legislação. Currículo. Metodologia.

\section{EDUCATION: A CURRICULAR CHILDHOOD ORGANIZATION AND A SUBJECTED METHODOLOGY WITH THE COMMON NATIONAL CURRICULAR BASE EXPERIENCE FIELDS}

\footnotetext{
Abstract: This article presents a reflective approach of the curricular organization that

${ }^{1}$ Graduada em Pedagogia pela UNITINS. Pós-graduação Lato sensu em Psicopedagogia pela FAEL. Aluna de Especialização em Pesquisa Avançada pela Faculdade Alpha e Mestranda Internacional pela Atenas College University. E-mail:anacleide292011@ hotmail.com.

${ }^{2}$ Graduado em Biologia Pela Universidade Federal Rural de Pernambuco (UFRPE), Doutor em Biologia pela Universidade Federal de Pernambuco, Professor e Coordenador do Curso de Mestrado em Direito Pela Faculdade ALPHA - Atenas College University - Estados Unidos. E-mail.: alphadiogenes@gmail.com.
} 


\section{Universidade do Extremo Sul Catarinense \\ Revista lbero-Americana de Humanidades, Ciências e \\ Educação

unesc

has today for Early Childhood Education with the promulgation of the BNCC and the curricular trajectory in the last decades through bibliographical revisions in the Brazilian legislations, in the bibliographies as books, scientific articles, magazines and electronic documents. contemporary and traditional in the search and allocation of knowledge about early childhood education, its importance and its trajectory all discussed by a theoretical framework that briefly conceptualizes the legislative landscape with the directives and curriculum references for early childhood education the very Common Base Curriculum for Early Childhood Education where this document reinforces the curricular organization and standardizes the activities at this stage with pillars established in Learning Rights and premises on six bases that are: Live, Play, Participate, Explore, Express and Know, to be developed in a context. $\mathrm{W}$ of experiments that enable children to develop through which the BNCC wisely presents as "fields of experience" and ultimately the active methodology which in its turn is not up to date emerged with the disruption of traditional pedagogy after many struggles of Its precursors, through their dedication to hard studies, were able to establish themselves for their proven effectiveness in the school and personal life of individuals when defended by several revolutionaries of world education. Here we bring Jean Piaget (1896-1980) who considers that knowledge The interaction between individuals and the objects of knowledge takes place, respecting each phase of the life of the being, especially with regard to the child's cognitive development. Piaget emphasizes that the educational system must create methods that enable this intentional interaction. that stimulate this construction, it is considered that the curricular trajectory has added value to are real for the social historical construction of early childhood education.

Keywords: Child Development. Legislation. Curriculum. Methodology.

\section{INTRODUÇÃO}

A Educação Infantil precisa ser caracterizada por sua importância no sistema educacional de forma que se perceba que o modo como desenvolvê-la viabiliza e assegura com garantia a construção de uma base que sustente firmemente toda a sucessível vida escolar dos indivíduos e por consequência formar gerações desejáveis para sociedade, uma vez que a criança é parte fundamental para este processo sendo de comum acordo que é nesta fase que se desenvolve e se constrói pilares para edificar as próximas fases do ser humano como bem preconiza a Lei de Diretrizes e Bases no art. 29:

\footnotetext{
A educação infantil é a primeira etapa da educação básica. É a única que está vinculada a uma idade própria: atende crianças de zero a três anos na creche e de quatro e cinco anos na pré-escola. Tem como finalidade o desenvolvimento integral da criança em seus aspectos físicos, psicológico, intelectual e social, complementando a ação da família e da comunidade (BRASIL, 1996)
}

De forma geral exercer o direito que se tem a uma Educação Básica de qualidade no Brasil não tem sido tarefa fácil, sobre tudo na primeira etapa que é a Educação Infantil, que comumente evidencia vários impasses, sejam os históricos desde sua fundação no 


\section{Universidade do Extremo Sul Catarinense \\ Revista Ibero-Americana de Humanidades, Ciências e \\ Educação \\ unesc

século passado aqui no Brasil, com uma visão pura e sistemicamente assistencialista, como também os impasses contemporâneos vivenciados pelos educadores que muitas vezes são desprovidos de formações adequadas inicial e/ou continuada para trabalharem com esse público onde se deparam também com ausências de estruturas físicas das unidades prediais destinadas para o atendimento às crianças nesta faixa etária que deveria viabilizar o desenvolvimento de atividades estruturantes e construtoras para seu público em atendimento, questões que foram tratados como metas a serem alcançadas com Plano Nacional de Educação (PNE) 2014-2024. Bem como as interferências externas e verticais que normatizam esse sistema como a atual Base Nacional Comum Curricular.

Diante de tais implicações, busca-se discutir de que forma o uso dos documentos normativos que norteiam os currículos escolares, como a BNCC pode contribuir na elaboração dos planos e nas atividades diárias para o desenvolvimento infantil das crianças de 0 a 3 anos? Se há possibilidade de elencar ganhos positivos na construção histórica da Educação Infantil com as promulgações legislativas e que contribua para o conhecimento reflexivo dos docentes frente à construção de currículos e planos de aula? Quais autores tradicionais e contemporâneos defendem a teoria de uma pedagogia ativa preconizada no "Campo das Experiências" da BNCC que passará a norteia a prática pedagógica sistematicamente de forma normativa?

Neste contexto objetiva-se dar visibilidade à Educação Infantil e sua importância no desenvolvimento integral das crianças, avaliar os mecanismos de normatização curricular e suas implicações diretamente no cotidiano escolar das unidades de educação infantil e comparar como o comportamento dos docentes frente a uma proposta incisiva da teoria de

\section{METODOLOGIA}

Neste trabalho utilizou-se de pesquisa bibliográfica com uma revisão das referências para o Estado da Arte, valendo-se de materiais já elaborados como: livros, artigos científicos, revistas e documentos eletrônicos na busca e alocação de conhecimento sobre currículo na educação infantil e sua importância de modo a dar visibilidade da importância do desenvolvimento integral das crianças nesta etapa educacional seus mecanismos sistemáticos e utilização do mesmo no planejamento de aulas e correlacionar tais conhecimentos com os resultados colhidos com pesquisa de campo através de aplicação de questionários junto aos docentes atuantes da Creche 


\section{Universidade do Extremo Sul Catarinense \\ Revista Ibero-Americana de Humanidades, Ciências e \\ Educação \\ unesc

Municipal Professora Jusete Barbosa Soares Lima, no Município de Ipojuca - PE.

Sendo esta com uma análise geral do corpo docente frente ao mais novo documento normativo (BNCC), seus mecanismos e utilização da mesma na formulação do currículo e do planejamento de aulas, acredita-se que com esta pesquisa seja possível demonstrar a eficácia da utilização dos dispositivos existentes que normatizam a Educação Infantil, garantindo a oportunidade de assegurar que crianças sejam desenvolvidas em um ambiente propício para este processo.

\section{FUNDAMENTAÇÃO TEÓRICA}

\subsection{Breve panorama legislativo da Educação Infantil}

Em 1998 a educação infantil ganhou um Referencial Curricular Nacional para a Educação Infantil (RCNEI) que representou um avanço para época onde buscou-se apontar metas de qualidade que contribuam para que as crianças tenham um desenvolvimento integral dos 0 aos 6 anos, subsidiando a elaboração de projetos educativos nas unidades de ensino (BRASIL, 1998).

Em 2009 apresentaram-se as Diretrizes Curriculares Nacionais para a Educação Infantil (DCNEI) que por sua vez trouxe um olhar mais voltado para as singularidades das crianças atendendo aos anseios da época nesta faixa etária apontando uma direção para a importância do brincar e dos cuidados pessoais associados a metodologias pedagógicas e tratando a crianças como:

Sujeito histórico e de direitos que, nas interações, relações e práticas cotidianas que vivência, constrói sua identidade pessoal e coletiva, brinca, imagina, fantasia, deseja, aprende, observa, experimenta, narra, questiona e constrói sentidos sobre a natureza e a sociedade, produzindo cultura (BRASIL, 2009)

As Diretrizes Curriculares Nacionais para Educação Infantil (DCNEI) desde então passou fazer parte do currículo acadêmico das formações iniciais dos docentes e a nortear o currículo das redes municipais de educação, estruturando os mesmos com considerações de princípios éticos, políticos e estéticos que deveriam subsidiar a produção do conhecimento nas escolas infantis organizando os objetos de conhecimento em oito eixos, devendo ser considerados de forma integrada: $1^{\circ}$ - movimento, $2 .^{\circ}$ - identidade e autonomia, $3 .^{\circ}-$ conhecimento de mundo, $4 .^{\circ}-$ artes visuais, $5 .^{\circ}-$ música, $6 .^{\circ}-$ linguagem oral e escrita, $7 .^{\circ}-$ natureza/sociedade e $8 .^{\circ}$ matemática os quais permaneceram até a 


\section{Universidade do Extremo Sul Catarinense \\ Revista Ibero-Americana de Humanidades, Ciências e \\ Educação \\ unesc

chegada da BNCC que, valida muitos aspectos da então (DCNEI), porém se contrasta com a forma de apresentação incisiva que dá de forma normativa, mas ambas não são currículo e sim orientações para formulação dos currículos das redes de ensino brasileiro.

A Lei mor a Constituição Federa de 1988 em seu Título VIII, Da Ordem Social no capítulo III que é o da Educação, da Cultura e do Desporto, traz a Seção I da Educação já previa a necessidade de se ter uma base comum curricular ao nível nacional que nivelassem os educandos com saberes mínimos como direito de aprendizagem com seguinte redação:

Art. 210. Serão fixados conteúdos mínimos para o ensino fundamental, de maneira a assegurar formação básica comum e respeito aos valores culturais e artísticos, nacionais e regionais (BRASIL, 1988)

Então pode-se compreender que a Base Nacional Comum Curricular é uma das estratégias estabelecidas pelo Plano Nacional de Educação (PNE) que, por sua vez, é o mecanismo utilizado para sistematizar a educação do país em todos os aspectos a BNCC emerge da necessidade de melhorar a educação básica, que abrange a educação infantil, o ensino fundamental e o médio. No caso da Educação Infantil pode-se constatar que a mesma tem recebido grandes incentivos governamentais nas últimas décadas a títulos de resoluções, como os programas "Brasil Carinhoso" e o "Proinfância" como podemos apreciar a seguir:

Resolução/CD/FNDE n. ${ }^{\circ}$ 25, de 14 de junho de 2013 - Estabelece os critérios de transferência automática de recursos a municípios e ao Distrito Federal, a título de apoio financeiro, para construção de unidades de educação infantil Próinfância, com utilização de Metodologias Inovadoras e dá outras providências. (BRASIL, 2013)

Resolução No 15, DE 6 DE DEZEMBRO DE 2017 que estabelece os procedimentos operacionais para a transferência obrigatória de recursos financeiros aos municípios e ao Distrito Federal, a título de apoio financeiro suplementar à manutenção e ao desenvolvimento da educação infantil para o atendimento de crianças de 0 a 48 meses informados no enso Escolar da Educação Básica, cujas famílias sejam beneficiárias do Programa Bolsa Família - PBF, beneficiárias do Benefício de Prestação Continuada - BPC, na forma estabelecida pela Lei no 8.742, de 7 de dezembro de 1993; ou pessoas com deficiência, em creches públicas ou conveniadas com o poder público, referente ao exercício de 2017. (BRASIL, 2017)

Porém, diante do exposto fica notório que os esforços políticos destinados para apoiar a infância no Brasil, se tornam muito pouco diante da grande população desassistida que se tem, oriundas de descasos históricos, sobre tudo nesta etapa da Educação Básica quando se depara, por exemplo, com os resultados das metas traçadas 


\title{
Universidade do Extremo Sul Catarinense \\ Revista Ibero-Americana de Humanidades, Ciências e \\ Educação \\ unesc

para educação infantil pelo PNE. O fracasso é gritante e os veículos de comunicações estampam os resultados negativos ano após ano, mostrando em suas manchetes que tais esforços foram insuficientes para garantir o alcance das mesmas, uma vez que os municípios não conseguem oferecer atendimento nem para garantir a meta que é de $50 \%$ "vale salientar" o total mínimo de crianças com idade de 0 a 3 anos que deveriam ser assistidas, logo se ver que os incentivos efetivos para esta politica pública andam em passos lentos e $40 \%$ do tempo estipulado já inspirou e muito se tem para caminhar. Das crianças em idade de creche, o descaso é grande como foi publicado recentemente pelo Diário de Pernambuco por Antônio Cruz, publicado em 07/06/2018.

\begin{abstract}
Das crianças até 3 anos, 31,9\% estavam em creches - Antônio Cruz/Arquivo Agência Brasil. $\mathrm{O}$ atendimento de crianças de até 3 anos também precisa aumentar. A lei estabelece que, até $2024,50 \%$ das crianças de até 3 anos estejam matriculadas em creches. Em 2016, essa porcentagem chegou a 31,9\%. Para atingir a meta, é necessário incluir, 1,9 milhão de crianças. Conseguir vaga em creches é difícil em diversas localidades, e pais, e responsáveis precisam enfrentar longas filas para ter acesso ao ensino público para as crianças.

"A cobertura para crianças de 0 a 3 anos apresenta tendência de crescimento da desigualdade entre regiões, áreas urbana e rural, negros e brancos, pobres e ricos", diz o texto, ao acrescentar que são necessárias "políticas para estimular os municípios a atenderem com prioridade, em creche, as crianças do grupo de renda mais baixo" (CRUZ, 2018)
\end{abstract}

Deixar tantas crianças excluídas de oportunidades de desenvolver-se de forma integral planejada e efetivada por profissionais de forma adequada, como se pode observar no que diz a Lei de Diretrizes e Bases (LDB)

Lei $N^{\circ} 9.394$ de 20 de dezembro de 1996 em seu artigo 29, é uma agressão, ou no mínimo negligência a um direito garantido por lei.

Mas a humanidade de modo geral e de certa forma tem aprendido a perseguir lutas por um mundo mais justo onde se busca alcançar os direitos básicos como educação, moradia, alimentação, saúde e outros. Sabendo-se que toda essa caminhada não é um fenômeno recente e que os ganhos são discretos diante das lutas, porém ha de se convir que o surgimento de conceitos conquistados na sociedade são inúmeros, aqui ficamos com o de "educação infantil" que vem desde o século passado modificando os sistemas sociais já existentes através de implantação de uma filosofia social mais justa e que corresponda a igualdade de oportunidade e efetivação de direito da criança pequena a uma educação pública de qualidade que lhe assegure condições de desenvolver-se de forma global, o que resta por hora é uma caminhada a favor da ampliação deste atendimento de 


\section{Universidade do Extremo Sul Catarinense \\ Revista Ibero-Americana de Humanidades, Ciências e \\ Educação \\ unesc

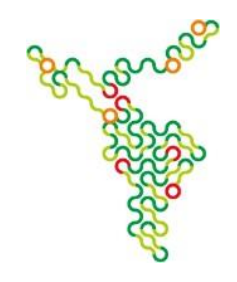

forma que não deixe nenhuma criança para trás.

Os aspectos que permeiam a normatização das políticas públicas no Brasil são comumente conturbados por conflitos advindo dos ideais entre os grupos responsáveis por tais feitos, dessa forma as políticas educacionais encontram impasses em sua efetivação uma vez que cada grupo quer implantar suas ideologias que muitas vezes não acorda com a ideologia que outrora se valia e como as políticas visam à intervenção estatal diretamente em pontos específicos da sociedade como a educação de exemplo, onde se busca uma intervenção alicerçada em promulgação de planos, diretrizes e estratégias que normatizem e direcionem a efetivação de uma política pública para resolução de questões gerais onde se investiu muito tempo, verbas, energias e estudos nas esferas federal, estadual e municipal como é o caso do Plano Nacional de Educação (PNE) 2014-2024 que se apresenta como importante instrumento, indispensável para o desenvolvimento da educação no país uma vez que emergiu da necessidade de unificar e sistematizar os objetivos, as diretrizes, as metas e as estratégias para a efetivação da educação em todo território nacional brasileiro.

Neste contexto cabe explicitar as metas extremamente importantes que foram traçadas para Educação Infantil do Plano Nacional de Educação 2014-2024 como se pode observar a seguir:

Meta 1 - Educação Infantil: Universalizar, até 2016, a educação infantil na préescola para as crianças de 4 (quatro) a 5 (cinco) anos de idade. Meta prevista: $100 \%$ situação $\quad 81.4 \%$ http://simec.mec.gov.br/pde/grafico_pne.php\#detail0001 acesso em 24/01/2019(...) E ampliar a oferta de educação infantil em creches de forma a atender, no mínimo, $50 \%$ (cinquenta por cento) das crianças de até 3 (três) anos até o final da vigência deste PNE. Meta prevista 50\%, situação atual 23.2\% http://simec.mec.gov.br/pde/grafico_pne.php\#detail0002 acesso em 24/01/2019.

1.5. Manter e ampliar, em regime de colaboração e respeitadas as normas de acessibilidade, programa nacional de construção e reestruturação de escolas, bem como de aquisição de equipamentos, visando à expansão e a melhoria da rede física de escolas públicas de educação infantil;

1.6. Implantar, até o segundo ano de vigência do PNE, avaliação da educação, a ser realizada à cada dois anos, com base em parâmetros nacionais de qualidade, a fim aferir a infraestrutura física, o quadro de pessoal, as condições de gestão, os recursos pedagógicos, a situação de acessibilidade, entre outros indicadores relevantes;

1.8. Promover a formação inicial e continuada dos (as) profissionais da educação infantil, garantindo, progressivamente, $\mathrm{o}$ atendimento por profissionais com formação superior;

1.10. Fomentar o atendimento das populações do campo e das comunidades indígenas e quilombolas na educação infantil nas respectivas comunidades, por meio do redirecionamento da distribuição territorial da oferta, limitando a 


\section{Universidade do Extremo Sul Catarinense \\ Revista Ibero-Americana de Humanidades, Ciências e \\ Educação

nucleação de escolas e o deslocamento de crianças, de forma a atender às especificidades dessas comunidades, garantido consulta previa e informada; 1.11. Priorizar o acesso à educação infantil e fomentar a oferta do atendimento educacional especializado, complementar e superior dos (as) alunos (as) com deficiência, transtornos globais do desenvolvimento e altas habilidades ou superdotação, assegurando, assegurando a educação bilíngue para crianças surdas e a transversalidade da educação especial nessa etapa da educação básica;

1.12. Implementar, em caráter complementar, programas de orientação e apoio às famílias, por meio da articulação das áreas de educação saúde e assistência social, com foco no desenvolvimento integral da criança de até três anos de idade;

1.13. Preservar as especificidades da educação infantil na organização das redes escolares, garantindo o atendimento da criança de zero a cinco anos em estabelecimentos que atendam a parâmetros nacionais de qualidade, e a articulação com a etapa escolar seguinte, visando ao ingresso do (a) aluno (a) de seis anos de idade no ensino fundamental;

1.14. Fortalecer o acompanhamento e monitoramento do acesso e da permanência das crianças na educação infantil, em especial dos benefícios de programas de transferência de renda, em colaboração com as famílias e com os órgãos públicos de assistência social, saúde e proteção a infância;

1.15. Promover a busca ativa de crianças em idade correspondente á educação infantil, em parceria com órgãos públicos de assistência social, saúde e proteção à infância, preservando o direito de opções da família em ralação as crianças de até três anos;

1.16. O Distrito Federal e os municípios, com a colaboração da União e dos estados, realização e publicação, a cada ano, levantamento da demanda manifesta por educação infantil em creches e pré-escolas, como forma de planejar e verificar o atendimento;

1.17. Estimular o acesso à educação infantil em tempo integral, para todas as crianças de zero a cinco anos conforme estabelecido nas Diretrizes Curriculares Nacionais para Educação Infantil. (BRASIL, 2014)

Conforme (MOTA, 2018) o PNE tem sua amplitude e importância pela abrangência e poder de alcance seja ideológico, seja pratico ou organizacional uma vez que pontua suas interferências através de metas e também por dar seguridade e providências, ou seja, o PNE preconiza o que tem que ser feito, como deve ser feito e ainda transfere provimento para que seja feito tudo que fora traçado nele e ainda é cabível de avaliações de todos esses processos estabelecidos.

O Plano Nacional de Educação (PNE) "[...] emerge como o principal instrumento de desenvolvimento da educação brasileira". Assim, esse documento sistematiza objetivos, diretrizes, metas e estratégias a serem alcançados, de modo a assegurar a consecução da política educacional brasileira (MOTA, 2018, p. 6)

Desta forma, podemos dizer que há um caminho que precisa ser trilhado, mas que já fora traçado, há um mapa para esse trilho, o que resta é optar caminhar por ele rumo ao sucesso da educação básica do Brasil, porém, na prática, há pouquíssimos esforços para 


\section{Universidade do Extremo Sul Catarinense \\ Revista Ibero-Americana de Humanidades, Ciências e \\ Educação \\ unesc

seguir nesta caminhada da implementação de políticas públicas que fora pensada por gestões anteriores, dá prosseguimento a planos que estão dando certo pelo contrário se menospreza uma vez que não é de práxis no sistema politico brasileiro tal feito e que é pior ainda, se gasta muito em tempo e em investimento para refazer os planos e se esquecem que, quem caminhará pelos trilhos seja de qual for a gestão serão os mesmos cidadãos de outrora ou os seus descendentes. Talvez o que falte é uma previsão de punição preconizada na forma da lei para os gestores governamentais em todas as esferas diante de suas omissões ou não alcance das metas que já fora traçada e subsidiada.

\subsection{BNCC e a Educação Infantil}

A Base Nacional Comum Curricular (BNCC) é um documento de caráter normativo que define o conjunto orgânico e progressivo de aprendizagem essencial que todos os alunos devem desenvolver ao longo das etapas e modalidades da Educação Básica no Brasil (BRASIL, 2017) e como tal, tem sido um dos assuntos mais recorrente na área educacional e não seria por menos afinal, se trata da normatização curricular das unidades de ensino básico brasileiro seja privado ou público. Aqui vamos analisar suas implicações na Educação Infantil, onde o referido documento reforça a organização curricular e normatiza as atividades nesta etapa com Direitos de Aprendizagens como premissas, em seguida apresenta o que podemos enxergar como seis bases que nortearam o desenvolvimento das aprendizagens cotidianas nas unidades educacionais, que são: Conviver, Brincar, Participar, Explorar, Expressar e Conhecer-se, a serem desenvolvidos em um contexto de concretude com experimentos que propicie a criança aprendente a desenvolver-se por meio do qual a BNCC sabiamente apresenta como "campos de experiências" estratégia didática que sempre fora defendida por precursores da pedagogia ativa. Sua apresentação é de fácil compreensão como podemos destacar na publicação de Rita Trevisan, na revista Nova Escola.

(...) A Base estabelece 5 Campos de Experiência fundamentais para o desenvolvimento das crianças. Eles são: Eu, o outro e o nós; Corpo, gestos e movimentos; Traços, sons, cores e formas; Escuta, fala, pensamento e imaginação; e Espaço, tempo, quantidades, relações e transformações.

Dentro dos Campos há objetivos de aprendizagem que são divididos em três grupos etários (bebês, crianças bem pequenas e crianças pequenas).

Os Campos de Experiência e os objetivos não têm caráter de currículo, mas servem para auxiliar o professor a planejar atividades com maior clareza do 


\section{Universidade do Extremo Sul Catarinense \\ Revista Ibero-Americana de Humanidades, Ciências e \\ Educação

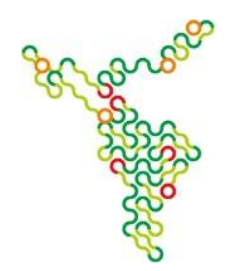

que deve ser desenvolvido em cada fase.

A Base estabelece Cinco Campos de Experiência para a Educação Infantil, que indicam quais são as experiências fundamentais para que a criança aprenda e se desenvolva. Os Campos enfatizam noções, habilidades, atitudes, valores e afetos que as crianças devem desenvolver do 0 aos 5 anos e buscam garantir os direitos de aprendizagem das crianças. Ou seja, o conhecimento vem com a experiência que cada criança vai viver no ambiente escolar.

Dessa forma, os Campos estão organizados de forma a apoiar o professor no planejamento de sua prática intencional. "As atividades propostas à criança devem ser bem planejadas, o próprio cuidar não pode ser algo mecânico. A criança precisa ter tempo e espaço para se expressar e o professor tem que estar aberto para acompanhar as reações dela, que serão sempre únicas e pessoais", explica a assessora pedagógica e formadora Silvana Augusto

Em outras palavras, é importante que as práticas do professor estejam diretamente comprometidas com as necessidades e os interesses da criança, para que a vivência se transforme em uma experiência e tenha, de fato, um propósito educativo.

"É preciso lembrar que a aprendizagem da criança se dá nas situações cotidianas, sempre de forma integrada, em contextos lúdicos, próximos às práticas sociais que lhes são significativas", complementa Beatriz Ferraz, consultora do Time de Autores de NOVA ESCOLA. Assim, mesmo quando o objetivo é apresentar conhecimentos culturais e científicos aos meninos e meninas da creche, é preciso levar em conta os Campos, como núcleos integradores das propostas a serem trabalhadas em sala de aula, além de considerar as interações e a brincadeira como forma de viabilizar o aprendizado das crianças (TREVISAN, 2018)

A promulgação da $\mathrm{BNCC}$ representa uma nítida preocupação bem-vinda à

Educação Infantil, sobretudo quando aborda o desenvolvimento global da criança, buscando por meio de "Campos de Experiência" estruturados em princípios éticos, políticos e estéticos como elementos norteadores na aquisição dos direitos e dos objetivos para a aprendizagem e o desenvolvimento da criança e que por isso se faz essencial considerar as orientações e as referências deste documento normativo na formulação dos currículos para os planos diários que assegure as crianças a viverem de forma criativa e desenvolver suas potencialidades através de experiências com o corpo; com as artes visuais, plásticas e sonoras (pinturas, sons, ritmos, danças, colagem, dobradura, escultura modelagem...); com as linguagens (marcas gráficas, expressão corporal, folear, desenhar, literaturas, faz de conta...); o altruísmo, as relações entre os pares e com os adultos (interações, modos de agir, socializações, conquistas e limitações, cuidados consigo e com o outro, autonomia, ...) ; a diversidade de cultura( vivenciar as diferentes formas de expressão cultural...) ; raciocínio lógico e matemático(classificação, seriação, simetria, posições, espaços, subir, descer, planejar, calendário, formas, operações,...), são apenas alguns dos exemplos de aprendizagens contemplados na BNCC para a Educação Infantil 


\title{
Universidade do Extremo Sul Catarinense \\ Revista lbero-Americana de Humanidades, Ciências e \\ Educação \\ unesc

desviando tal etapa das tão citadas datas comemorativas, assistencialismo, só brincar ou mesmo ideologias próprias da gestão por imposição sem avaliações por pares.

\begin{abstract}
Entretanto, embora reconhecida como direito de todas as crianças e dever do Estado, a Educação Infantil passa a ser obrigatória para as crianças de 4 e 5 anos apenas com a Emenda Constitucional n. ${ }^{0}$ 59/200 926, que determina a obrigatoriedade da Educação Básica dos 4 aos 17 anos. Essa extensão da obrigatoriedade é incluída na LDB em 2013, consagrando plenamente a obrigatoriedade de matrícula de todas as crianças de 4 e 5 anos em instituições de Educação Infantil. (BRASIL, 2017)
\end{abstract}

Logo, vê-se que por mais que se tenha uma Base Nacional Comum Curricular tão bem preparada para atender as peculiaridades no desenvolvimento das crianças na Educação Infantil, não surtirá os efeitos que se visa porque se esbarra em emendas que segregam as crianças quando separa a infância em dois blocos onde um tem atendimento obrigatório e o outro não, ora se entende que as fases se complementam e não que há uma com maior ou menor importância que a outra e se for por esse lado há inúmeros defensores de quê dos zero aos três anos é a idade com maior intensidade no desenvolvimento global do ser.

A BNCC não pode e nem deve ser confundida com currículo ela é um referencial normativo que preconiza em forma lei os direitos mínimos de aprendizagem para todos os brasileiros, independente de sua geografia habitacional, seja da escola pública, seja da escola particular. Para tanto se deve investir na formação continuada dos docentes de modo a incorporar as performances que a BNCC exige no que cerne a metodologia ativa que envolve todos os direitos de aprendizagem dos educandos que foram estabelecidos por ela.

\subsection{Metodologia ativa e a Educação Infantil}

A metodologia ativa é um processo amplo e possui como principal característica a posição do aprendiz que passa a ser o agente principal no desenvolvimento de sua aprendizagem, (que por sua vez não vem pronta a ser assimilada) ficando na posição central onde fará interações entre o objeto do conhecimento, o mediador e o meio uma vez que rompeu-se com muitos esforços a pedagogia tradicional centrada no mestre arraigada em decoração de exercício pronto para uma avaliação punitiva e seletiva onde os meios não interessavam e sim o fim. Essa metodologia fora defendida por precursores da pedagogia ativa e por vários pensadores dentre eles o Jean Piaget (1896-1980) que 


\section{Universidade do Extremo Sul Catarinense \\ Revista Ibero-Americana de Humanidades, Ciências e \\ Educação \\ unesc

sendo psicólogo não mediu esforços em contribuir para educação no que cerne o desenvolvimento cognitivo da criança e que muito contribuiu para educação escolar com suas visões revolucionárias, Piaget já se posicionava a favor da interação social como elemento fundamental na formação dos indivíduos, desta forma faz se necessário, um olhar afetuoso dos atuantes em unidades de Educação Infantil para com as crianças que estão em atendimento nesta fase que é tão importante, pois precede como base na escolarização do ser humano. Para Piaget:

Se tomarmos a noção do social nos diferentes sentidos do termo, isto é, englobando tanto as tendências hereditárias que nos leva a vida em comum e à imitação, como as relações "exteriores" (no sentido de Durkheim) dos indivíduos entre eles, não se pode negar que, desde o nascimento, o desenvolvimento intelectual é, simultaneamente, obra da sociedade e do indivíduo. (PIAGET, 1973 apud LA TAILLE, 1992, p. 11)

Indivíduo que por sua vez advém de conjunturas específicas e peculiares que o torna único em meio a uma diversidade imensurável em seus aspectos literais, porém é notória a relutância de se dar visibilidade e de integrar a creche (crianças de 0 aos 3 anos) efetivamente ao sistema educacional. Jean Piaget (1896-1980) muito contribuiu para que a criança deixasse de ser pensada e planejada para se tornarem miniatura de adultos, e também de tantos outros conceitos que passaram as crianças ao longo da evolução histórica da humanidade até que passasse a enxergar a criança como ser social em pleno desenvolvimento e fossem incumbidas dedireitos como o de uma educação que the assegure o desenvolvimento de suas potencialidades em cada fase vivida. Para tanto se tem a necessidade de pensar no currículo para esta etapa que hoje se ver na BNCC a prevalência de uma pedagogia ativa que há muito Piaget defendia como podemos constatar a seguir:

Não se aprende a experimentar simplesmente vendo o professor experimentar, ou dedicando-se a exercícios já previamente organizado: só se aprende a experimentar, tateando, por si mesmo, trabalhando ativamente, ou seja, em liberdade e dispondo de todo o tempo necessário (PIAGET, 1949, p. 39 apud MUNARI, 2010, p.18).

Piaget deixa claro nestas linhas supracitadas a importância de se construir escolas ou transformar as que já se tem em espaços sociais interacionista para oportunizar o aprender fazendo, vivenciando, experimentando. Entende-se também que quando o autor faz menção ao tempo, quer passar a importância de oportunizar o tempo necessário quanto à aprendizagem das crianças em cada fase sem o atropelo das mesmas para o 


\title{
Universidade do Extremo Sul Catarinense Revista Ibero-Americana de Humanidades, Ciências e Educação

desenvolvimento pleno de suas funções cognitivas. Ainda de acordo com Piaget:

\begin{abstract}
A aprendizagem é ativa; um dos temas recorrentes da teoria de desenvolvimento intelectual de Piaget é o conceito da aprendizagem como um processo pessoal e ativo. Do nascimento a infância, disse ele, a aprendizagem decorre de um desejo natural de sentir, explorar, mexer e, por fim dominar. Por esse motivo, Piaget não confiava muito em testes de inteligência padronizados, nos quais as crianças são submetidas a testes pré-formatados, cujas respostas "corretas" produzem medidas quantitativas da inteligência. Quando trabalhou com os testes padronizados de inteligência de Alfred Binet, no início dos anos 1920, ficou mais interessado nas respostas em si do que na capacidade das crianças de dar respostas corretas. As explicações das crianças sobre suas respostas revelam que as suas suposições infantis sobre o funcionamento do mundo são muito diferentes da forma de pensar dos adultos. Piaget ficou convencido de que além de crianças e adultos pensarem de maneiras diferentes as crianças de idades diferentes têm métodos distintos de pensamentos. (HERMETO e MARTIS. 2012, p. 265).
\end{abstract}

De modo geral, a pedagogia ativa vem tomando espaço significativo no sistema brasileiro de educação básica e é muito comum se deparar com veículos de comunicação que apoiam essa ideia e trazem o tema para debate, reflexão e conhecimento entre os pares nesta área como é o caso da revista NOVA ESCOLA;

São muitos os benefícios ao trazer as metodologias ativas para dentro da sala de aula. Entre os que pontuo a seguir, o principal é a transformação na forma de conceber o aprendizado, ao proporcionar que o aluno pense de maneira diferente (já ouviu falar em fora da caixa?) e resolver problemas conectando ideias que, em princípio, parecem desconectadas. Autonomia, aptidão em resolver problemas, colaboração, senso crítico, protagonismo, confiança, aprendizado, envolvente, empatia, responsabilidade e participação.

É importante investir em conteúdos atrativos e interativos, sendo essencial ter esse olhar para aprimorar os procedimentos utilizados para envolver os alunos na aprendizagem.

Para José Moran, as metodologias precisam acompanhar os objetivos pretendidos. Se queremos que os alunos sejam proativos, precisamos adotar metodologias em que os alunos se envolvam em atividades cada vez mais complexas, em que tenham que tomar decisões e avaliar os resultados, com apoio de materiais relevantes. Se queremos que sejam criativos, eles precisam experimentar inúmeras possibilidades de mostrar sua iniciativa. (GAROFALO, 2018)

Apoiar essa causa é investir em aprendizagem satisfatória de forma prazerosa sobre tudo na Educação Infantil e não confundi com "brincar por brincar" que, por sua vez, nos traz o tema ludicidade que é comumente muito complexo e se faz necessário, defesas científicas contemporâneas mesmo sabendo que a BNCC traz a pedagogia ativa como norma para Educação Infantil seus preceitos e seus conceitos precisam está internalizados pelos adultos atuantes para que não caiam no risco da confusão que se faz com o construtivismo nas escolas públicas onde se ver crianças brincando para "brincar 


\section{Universidade do Extremo Sul Catarinense \\ Revista Ibero-Americana de Humanidades, Ciências e \\ Educação \\ unesc

por brincar" enquanto podiam ou deviam estar "aprendendo brincando" ou ainda "brincando de aprender" e mesmo que a BNCC venha apontando que todos os momentos vividos pelas crianças em unidades educacionais devem ser previamente planejados e avaliados com intuito de favorecer a aprendizagem significativa que lhes é por direito.

Ainda de acordo com Piaget se almejamos formar cidadãos críticos e capazes de transformar suas realidades, devemos abdicar dos métodos pedagógicos análogos aos tradicionais rompendo com paradigmas que insistem em se firmar nos cotidianos escolares que acomodam o educador e facilitam a mecanização das atividades com mera transmissão do objeto do conhecimento pronto e acabado como verdades prontas e absolutas dos transmissores para os receptores, como se pudéssemos moldar a formação intelectual das mesmas por atividades repetitivas prontas a serem assimiladas sem nenhuma interação entre os componentes essenciais que formam o ambiente educacional (PIAGET, 2017. 23)

\section{RESULTADOS E DISCUSSÃO}

Foi constatado que todo corpo docente da unidade em pesquisa é predominante feminino com formação inicial em licenciatura em Pedagogia (gráfico 1) atuado em educação a mais de dez anos (gráfico 2) e em educação infantil mais de 50\% delas estão a menos de cinco anos (gráfico 3). A instituição não conta com Projeto Politico Pedagógico o que foi constatado presencialmente com a gestão da unidade o que justifica os dados do gráfico 4, como se não bastasse o município não tem um plano curricular municipal de educação o que foi constatado junto a secretaria de educação na figura da diretora de ensino Sr Silvia Helena onde a mesmo declarou informalmente que já estão em processo de formação equipes para trabalhar em cima da construção do currículo educacional para o município. Com relação aos instrumentos macros que norteiam ou deveriam nortear os currículos, foi visto que nenhuma docente demostrou conhecimento da utilização da RCNEI para orientação curricular, uma vez que os gestores orientam a utilização do currículo estadual para planejamentos sistemáticos das aulas, uma única professora esboçou conhecimento do DCNEI enquanto direcionador de currículo para educação infantil, já quando foi perguntado sobre a BNCC todas a reconheceram como documento orientador curricular para planejamento das atividades da educação na totalidade e para educação infantil, (gráfico 6). 
Universidade do Extremo Sul Catarinense

Revista Ibero-Americana de Humanidades, Ciências e

Educação

unesc

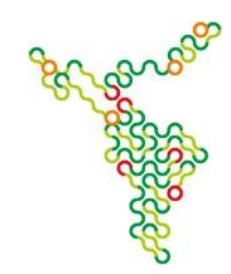

Ficou de comum acordo que todas utilizam sempre a BNCC para planejamento das atividades, por se tratar de um documento normativo, pelo fato do município ter oferecido formações continuadas sobre a BNCC, por ser de fácil compreensão na sua formatação quando trata os direitos de aprendizagens de acordo

com a idade da criança e a especificidade do que, e como se deve abordar tais direitos o que conduz a facilitação do trabalho no planejamento e afugenta os achismos alheios que por vez surge de maneira vertical, visto que o município ainda não tem um plano curricular próprio de educação traçado o que vulnerava as orientações e articulações gerenciais locais antes da promulgação da Base Nacional Comum Curricular.

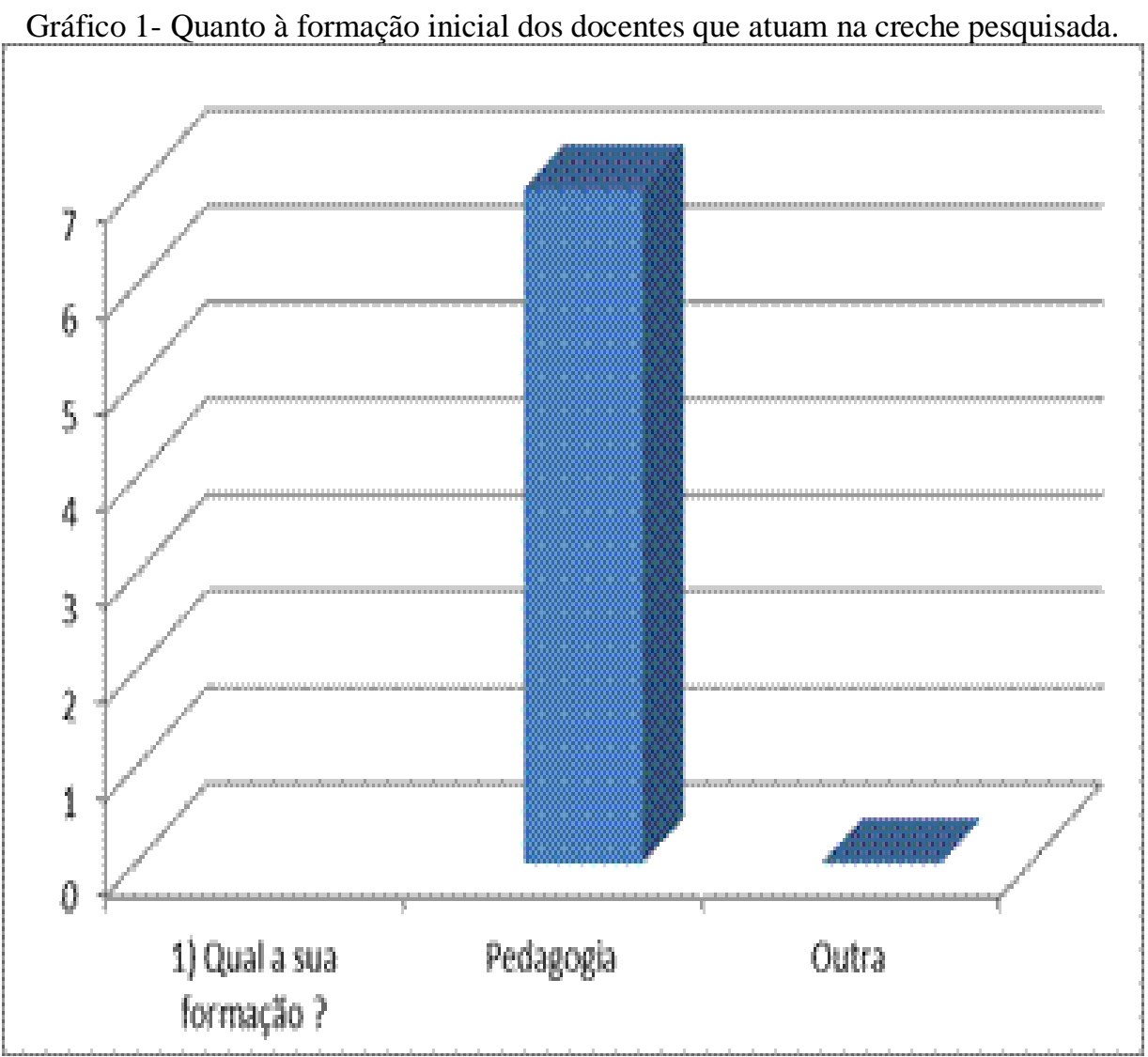

Autoria própria

De forma expressiva, a formação dos docentes que atuam nesta unidade demonstra o cuidado do município em trazer para suas unidades, profissionais minimamente preparados para atuarem na formação direta dos alunos em idade de creche esta atitude é plausível e com certeza o fruto será colhido lá na frente com o sucesso destes alunos nas próximas etapas de escolarização. 
Universidade do Extremo Sul Catarinense

Revista lbero-Americana de Humanidades, Ciências e

Educação

UneSC Produção e democratização do conhecimento na lbero-América

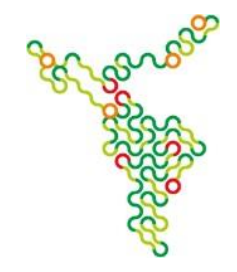

Gráfico 2- Quanto ao tempo/experiência de atuação em docência de forma geral.

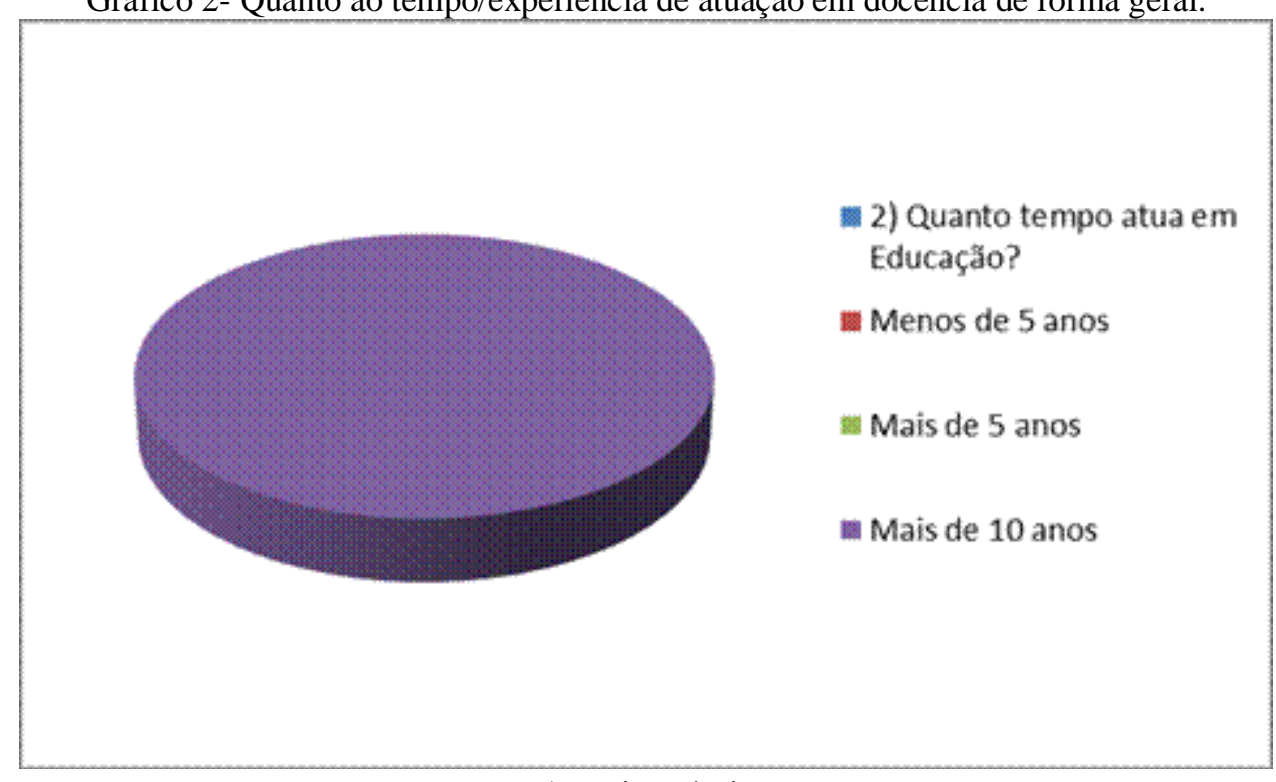

Autoria própria

Como pode ser observado, os docentes desta unidade têm um mínimo de dez anos de experiência na docência de forma geral, isso pode ter várias implicações uma delas pode ser que ter passado por outras experiências de turmas diferentes das de Educação Infantil favoreça ao docente a percepção dos prós e dos contra e finde em autoconhecimento do perfil de alunado ao qual se tenha aptidão para atuação.

Gráfico 3- Quanto ao tempo/experiência especificamente em Educação Infantil

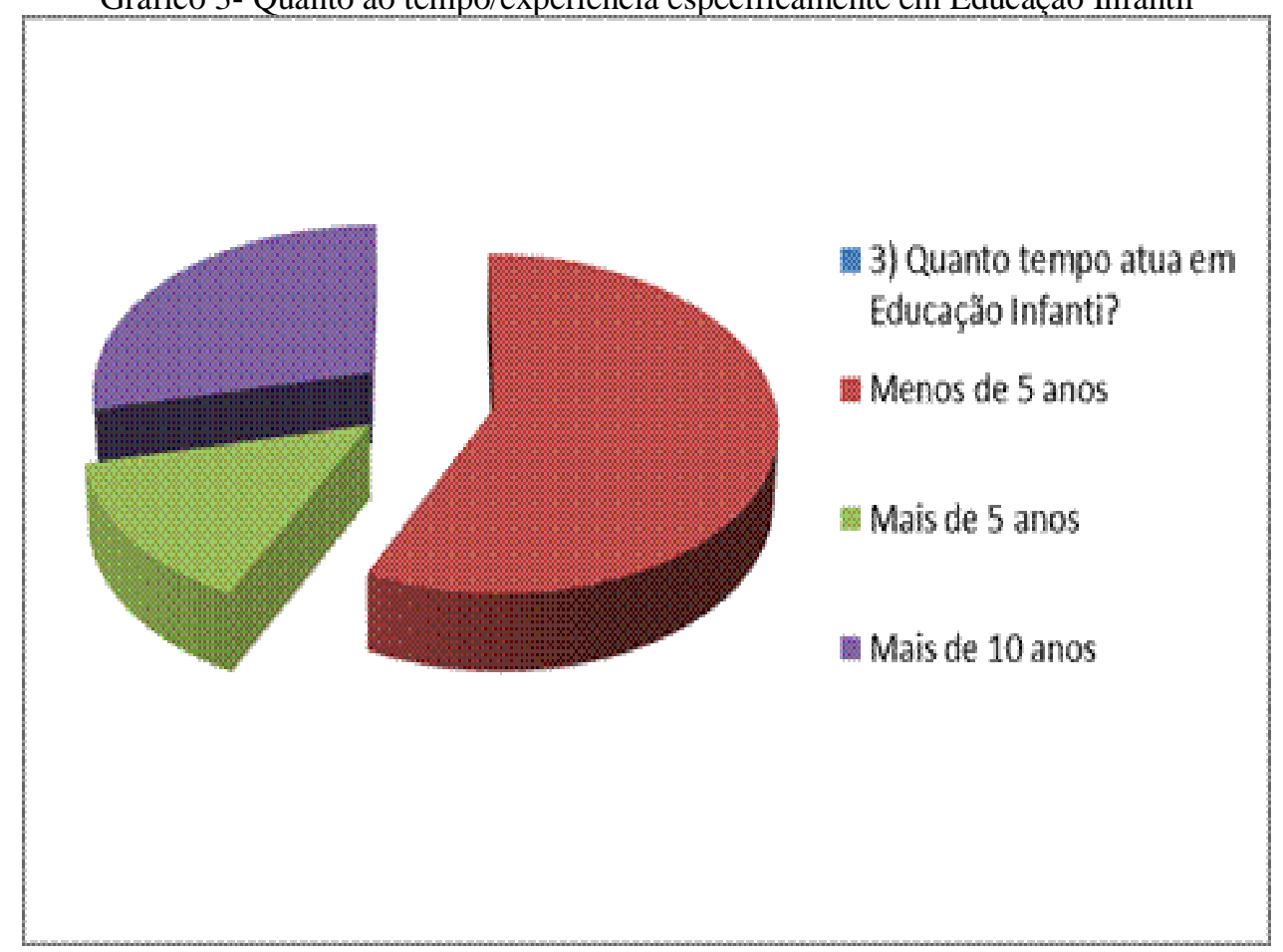

Revista Ibero-Americana de Humanidades, Ciências e Educação. Criciúma, v. 6.n.2, 2020. 


\section{Universidade do Extremo Sul Catarinense}

\section{Revista Ibero-Americana de Humanidades, Ciências e}

\section{Educação}

Autoria própria

Aqui fica posto que os docentes desta unidade tenham em sua maioria mais de cinco anos de experiência com a Educação Infantil o que é de suma importância na formação dos alunos e nas relações cotidianas na unidade uma vez que a troca de experiência enriquece os envolvidos e favorece novas descobertas no dia a dia.

A experiência também favorece o gerenciamento de forma que as tomadas de decisões precisam ser compartilhadas e essa partilha tem maior proveito se os componentes já tiverem o mínimo de consciência das implicações de suas tomadas de decisões e ainda põe em prática a gestão democrática ou pelo menos um dos seus aspectos.

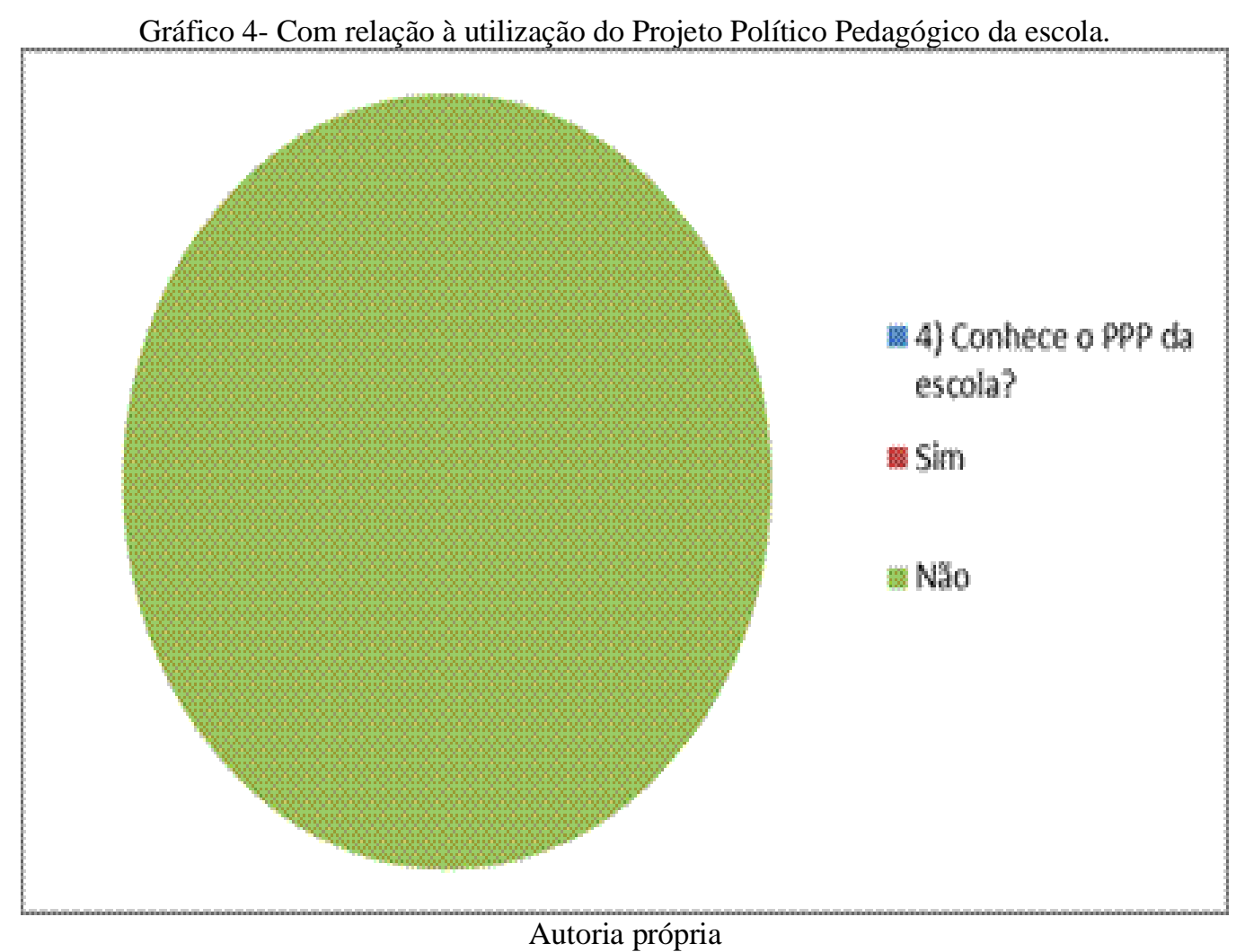

Diante do expressivo não ao conhecimento do Projeto Político Pedagógico desta escola fora perguntado informalmente a gestora da unidade o porquê deste fato e a mesmo destacou que acabara de assumir a gestão da unidade a qual fora desmembrada de outra unidade e que não tinha tido tempo hábil ainda para ter feito o PPP da creche. 
Universidade do Extremo Sul Catarinense

Revista Ibero-Americana de Humanidades, Ciências e

Educação

UneSC Produção e democratização do conhecimento na lbero-América

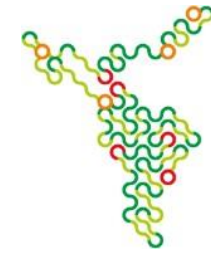

Gráfico 5 - Quanto ao Plano Municipal de Educação

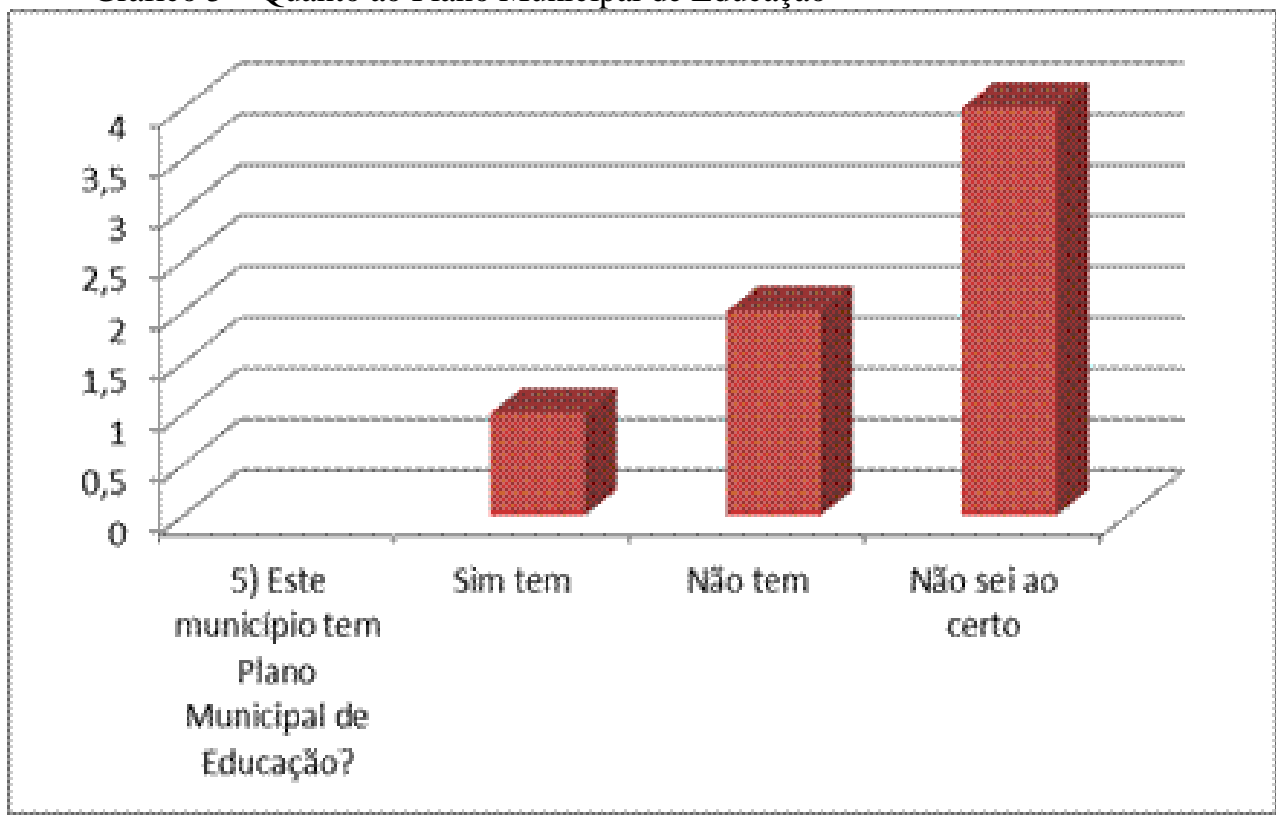

Autoria própria

Neste caso, os docentes ficaram indecisos e em sua maioria respondeu que o município não tem um Plano Municipal Educação. Aqui vale ressaltar que sim, o município tem um Plano que fora publicado pela Lei 1.806 no dia 22 de junho de 2015 (PME 215-2025). Nele estão traçadas as metas que consideram as metas do Plano Nacional de Educação (PNE 2014-2024) e estabelece as estratégias para o alcance dessas metas e sofre avaliação plurianual.

Gráfico 6- Quanto ao Referencial Curricular que embasa legalmente os planejamentos didáticos da unidade.

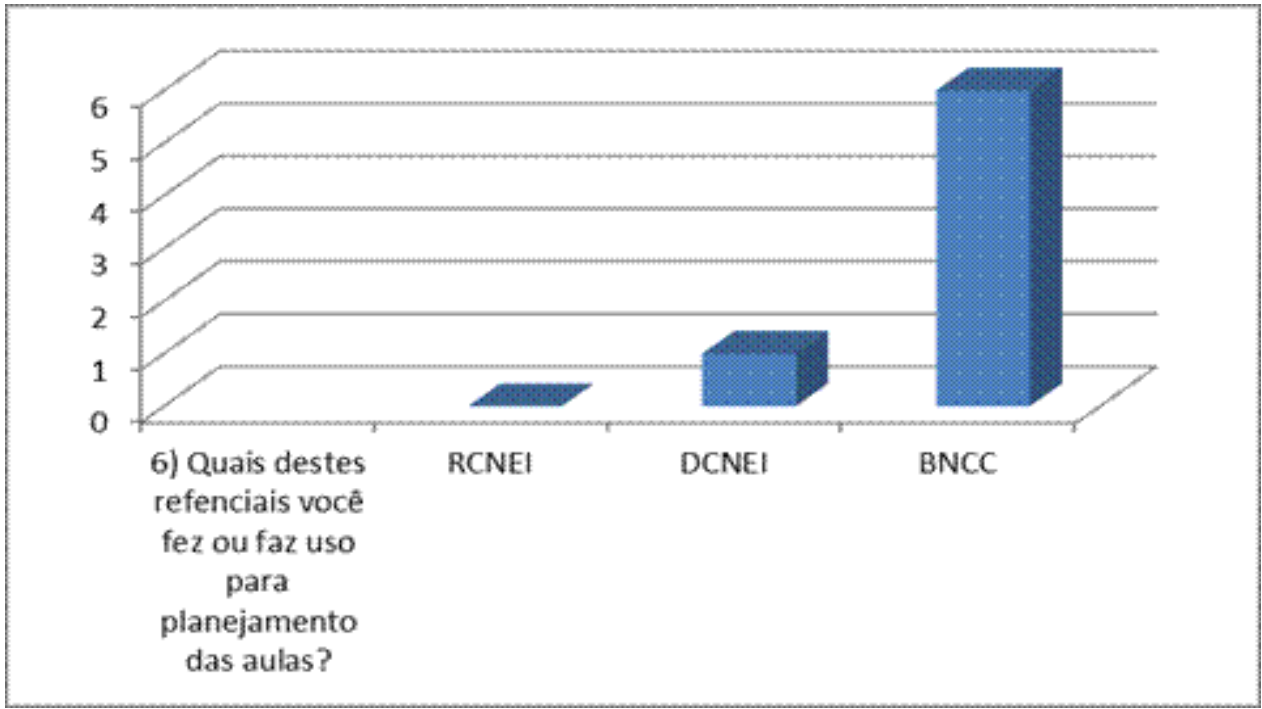

Autoria própria

Revista Ibero-Americana de Humanidades, Ciências e Educação. Criciúma, v. 6.n.2, 2020. 


\section{Universidade do Extremo Sul Catarinense \\ Revista Ibero-Americana de Humanidades, Ciências e \\ Educação \\ unesc

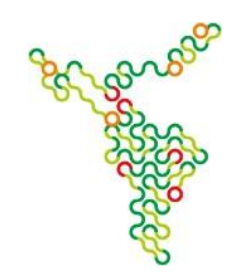

O referencial curricular é de suma importância para embasar legalmente o plano pedagógico das instituições de ensino, o uso dos referenciais nacionais é o mais indicado para não fugir do real interesse da educação do país na totalidade, neste caso os docentes deram preferência à BNCC mas também usam a DCNEI, nada contra até porque a BNCC não invalida os outros referenciais que a precederam.

$\mathrm{O}$ que pode ter implicado nesta preferência pode ter sido que a BNCC veio com força de lei e incisivamente os sistemas de educação no Brasil tiveram que abraçá-la, dispensando investimentos para formação continuada e debates sobre a mesma e ainda a imprensa também deu bastante força para o conhecimento da implantação da BNCC no sistema educacional do país.

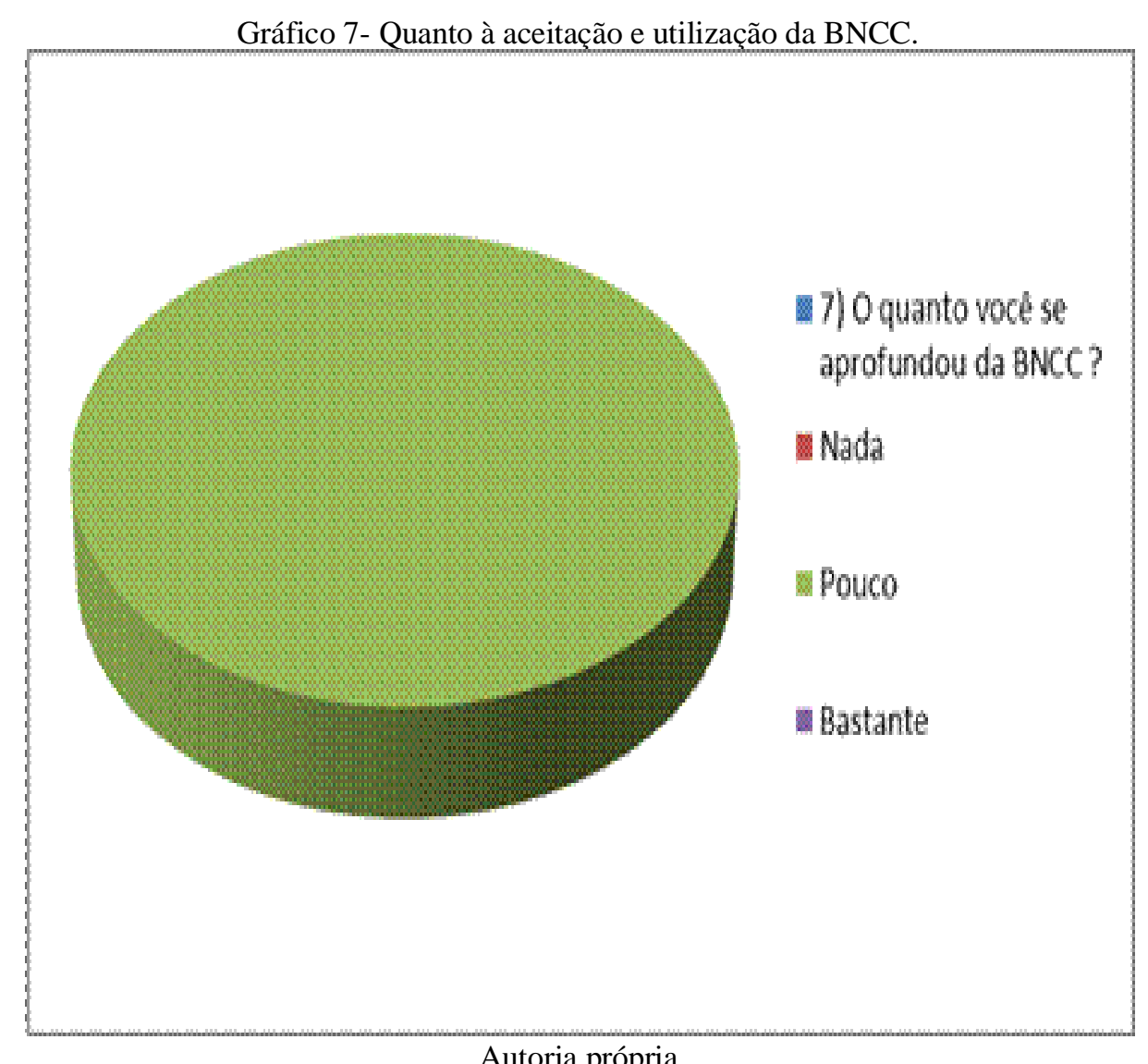

Este resultado trouxe um pouco de preocupação pelo fato de que os docentes já haviam respondido à preferência em utilizar a BNCC nos seus planejamentos de aulas e agora se mostram pouco conhecedores de um mecanismo que utiliza é de certa forma no mínimo contraditória. Porém, no gráfico abaixo está a resposta para este feito a preferência, na verdade, é uma imposição. 


\section{Universidade do Extremo Sul Catarinense \\ Revista lbero-Americana de Humanidades, Ciências e \\ Educação \\ unesc \\ Produção e democratização do conhecimento na lbero-América}

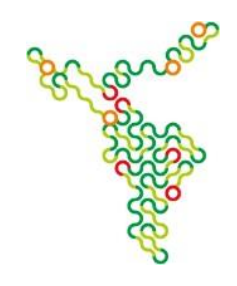

Gráfico 8- Quanto a imposição do uso da BNCC.

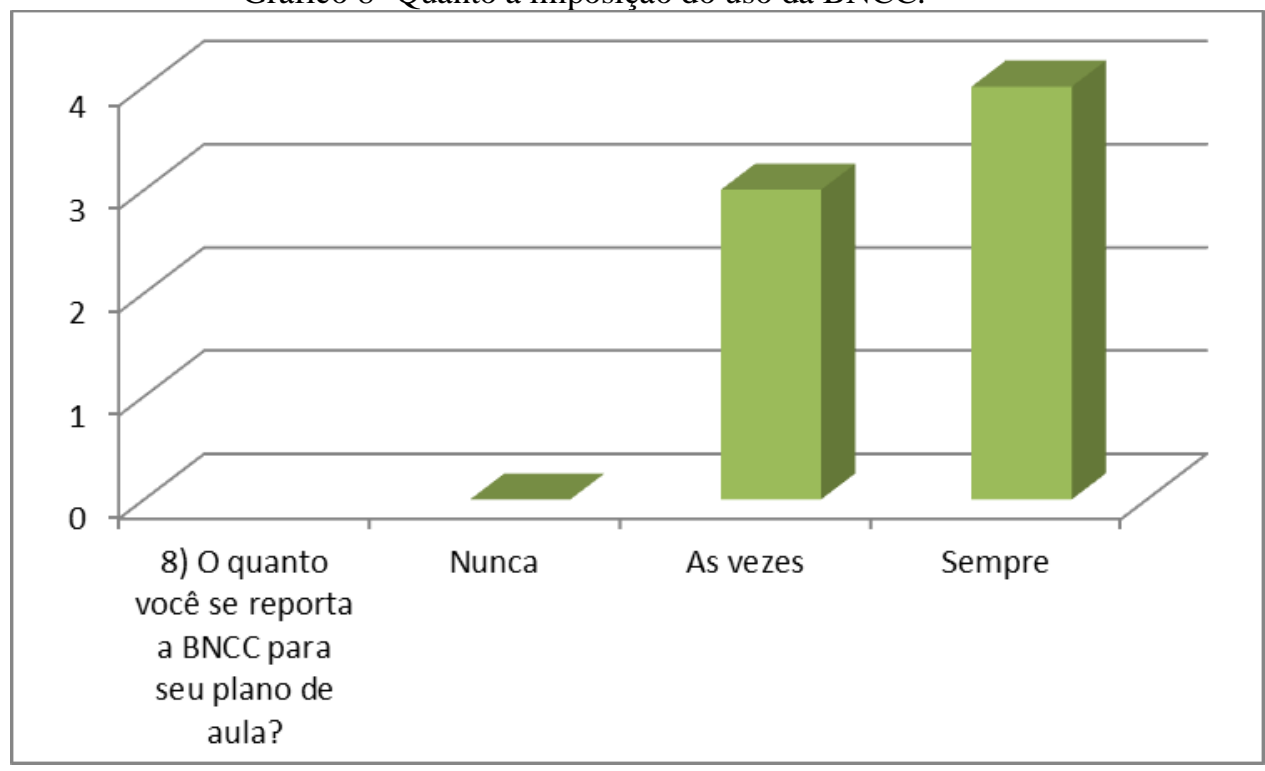

Autoria: Própria

\section{CONSIDERAÇÕES FINAIS}

Contudo, pode-se considerar que desde muitas décadas se debruça em direcionar verticalmente as atividades promovidas nas instituições de educação pública destinada à educação infantil que teve seu início puramente assistencialista durante décadas até que se viu a necessidade de unir o cuidar com o educar e então foi pertinente a elaboração do Referencial Curricular Nacional para Educação Infantil (RCNEI), depois de uma década os avanços nos estudos apontaram para a ampliação da obrigatoriedade do ensino o expandido, passando a compreender a partir dos 4 anos e não mais dos 6 anos como outrora, ou seja, ainda na educação infantil.

Em 2009 apresentaram-se então as Diretrizes curriculares nacionais para a educação infantil (DCNEI) o que foi um grande avanço, pois se buscou assegurar a direção desta etapa para a garantia de viabilizar o desenvolvimento da criança, respeitando suas singularidades e seus direitos com supremacia no direito do "brincar" onde trouxe os objetos do conhecimento fixado em eixos temáticos, podemos considerar então que a educação infantil ganhou muito em currículo nestas décadas citadas, porém aponta-se que a humanidade vive em constante evolução e se faz necessário criar mecanismos que acompanhe essas evoluções humanitárias e viabilizem futuras transformações com inclusão das atualidades culturais o que com a chegada da Base Comum Curricular (BNCC) obrigatoriamente no ano em curso é discorrido nas 10 


\section{Universidade do Extremo Sul Catarinense \\ Revista Ibero-Americana de Humanidades, Ciências e \\ Educação \\ unesc

competências gerais e então os ganhos agregados a educação básica como um todo é nítida já na educação infantil se superam seja no aspecto ideológico com o respeito das fases do desenvolvimento infantil e as temáticas divididas entre ela por meio dos campos de experiência "o eu, o outro, e nós"; "corpo, gestos e movimento"; "traços, sons, cores e formas"; "espaços, tempos, quantidades, relações e transformações"; "escuta, fala, pensamento e imaginação, seja pela indução metodológica obrigatoriamente ativa que deve ser assumida pelos envolvidos diretamente neste cenário onde o ideal é prezar e constituir espaços que favoreçam a interação entre a criança, os pares, o objeto do conhecimento e os mediadores de forma experimental, tátil, sensorial e afetiva, seja pela fácil compreensão da sua apresentação gráfica com uma linguagem acessível, seja pela acessibilidade nas formatações digitais, ou seja, ainda pelos debates/congressos/formações continuadas conforme orientação federal.

Logo se acorda que a BNCC coopera para o alcance das metas do Plano Nacional de Educação (PNE) no que compreende o desenvolvimento integral da criança e na garantia dos direitos de aprendizagens das mesmas, nivelado por base, desta forma conclui-se que se este documento não for engavetado e passar a ser utilizado na formulação dos currículos educacionais de forma fidedigna, pode-se esperar grandes avanços na aprendizagem das crianças nesta etapa educacional o que pode ser estudado, apurado, verificado através de estudos científicos in loco por pessoas idôneas ao tema ou que queira se inteirar do mesmo. Contudo, ficou constatado com a pesquisa de campo que os docentes aprovaram a BNCC e já estão fazendo uso da mesma para planejamento das atividades e a classificam como um marco referencial que só tem a contribuir para a educação infantil.

\section{Bibliografia}

BRASIL. Constituição Federal. senado.leg.br, 1988. Disponivel em: <https://www.senado.leg.br/atividade/const/con1988/con1988_15.12.2016/art_210_.asp >. Acesso em: 08 jul 2019.

BRASIL. Lei n. ${ }^{\circ}$ 9.394, de 20 de dez de 1996. Lei de Diretrizes e Bases, 1996. Disponível em: <http://www.planalto.gov.br/ccivil_03/LEIS/L9394.htm>. Acesso em: 14 jan 2019.

BRASIL. Referencial curricular nacional para a educação infantil. portal.mec.gov.br, 1998. ISSN vol 3. Disponível em: 


\section{Universidade do Extremo Sul Catarinense \\ Revista lbero-Americana de Humanidades, Ciências e \\ Educação \\ UneSC Produção e democratização do conhecimento na lbero-América}

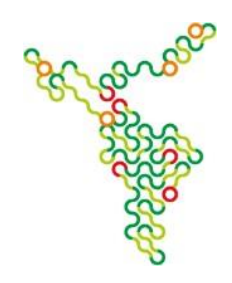

<http://portal.mec.gov.br/seb/arquivos/pdf/volume3.pdf>. Acesso em: 06 jul 2019.

BRASIL. Resolução no 5, de 17 de dezembro de 2009. ndi.ufsc.br, 2009. Disponível em: <http://ndi.ufsc.br/files/2012/02/Diretrizes-Curriculares-para-a-E-I.pdf>. Acesso em: 06 jul 2019.

BRASIL. Resolução/CD/FNDE n ${ }^{\circ}$ 25, de 14 de junho de 2013. Estabelece os critérios de transferência automática de recursos a municípios e ao Distrito Federal, a título de apoio financeiro, para construção de unidades de educação infantil - Proinfância, com utilização de Metodologias Inovadoras e dá..., 2013. Disponível em: $<$ http://www.fnde.gov.br/index.php/programas/proinfancia/sobre-o-plano-ouprograma/legislacao>. Acesso em: 20 jan 2019.

BRASIL. Lei $n^{\circ}$ 13.005, de junho de 2014. Plano Nacional de Educação 2014-2024, Brasília, DF, jun 2014. Disponível em: $<$ https://books.google.com.br/books?id=XOH0CQAAQBAJ\&lpg=PT55\&dq=educa\%C 3\%A7\%C3\%A3o\%20infantil\%20\%C3\%A9\%202015\&hl=pt-

$\mathrm{BR} \& p g=\mathrm{PT} 3 \# \mathrm{v}=$ onepage $\& \mathrm{q}=$ educa $\% \mathrm{C} 3 \% \mathrm{~A} 7 \% \mathrm{C} 3 \% \mathrm{~A} 3 \mathrm{o} \% 20 \mathrm{infantil} \% 20 \% \mathrm{C} 3 \% \mathrm{~A} 9 \% 2$ 02015\&f=false $>$. Acesso em: 05 maio 2019.

BRASIL. Resolução CNE/CP $\mathrm{n}^{\circ}$ 2, de 22 de dezembro de 2017. institui e orienta a implantação da Base Nacional Comum Curricular a ser respeitada obrigatoriamente ao longo das etapas e respectivas modalidades no âmbito da Educação Básica., 2017. Disponivel em: <http://portal.mec.gov.br/conselho-nacionalde-educacao/base-nacional-comum-curricular-bncc>. Acesso em: 14 jan 2019.

BRASIL. Resolução No 15, DE 6 DE DEZEMBRO DE 2017. Estabelece os procedimentos operacionais para a transferência obrigatória de recursos financeiros aos municípios e ao Distrito Federal, a título de apoio financeiro suplementar à manutenção e ao desenvolvimento da educação infantil para o atendimento de..., 2017. Disponível em: <http://www.fnde.gov.br/index.php/programas/brasil-carinhoso/sobre-o-plano-ouprograma/legislacao>. Acesso em: 20 jan 2019.

CRUZ, A. Educação. diariodepernambuco.com.br, Pernambuco, 07 jun 2018. Disponível em: <http://www.diariodepernambuco.com.br/app/noticia/brasil/2018/06/07/interna_brasil,7 54446/mais-criancas-estao-na-escola-mas-ainda-e-preciso-incluir-1-9-milhao.shtml>. Acesso em: 24 jan 2019.

GAROFALO, D. NOVA ESOLA. novaescola.org.br, jun 2018. Disponível em: $<$ https://novaescola.org.br/conteudo/11897/como-as-metodologias-ativas-favorecem-oaprendizado?imprimir=true $>$. Acesso em: 10 mai 2019.

HERMETO, C. M.; MARTINS, A. L. O Livro da Psicologia. São Paulo: Globo, 2012. MOTA, A. D. M. PLANO NACIONAL DE EDUCAÇÃO: ASPECTOS DA POLÍTICA 
Universidade do Extremo Sul Catarinense

Revista lbero-Americana de Humanidades, Ciências e

Educação

Unesc Produção e democratização do conhecimento na llbero-América

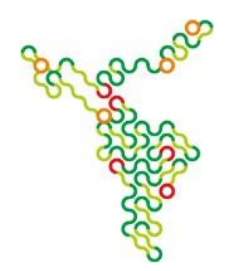

EDUCACIONAL. eventos.set.edu., $2018 . \quad$ Disponível em: <https://eventos.set.edu.br/index.php/enfope/article/view/8868/4085>. Acesso em: 05 maio 2019.

MUNARI, A. Jean Piaget. Recife: Massangana, 2010.

PIAGET, J. Psicologia e Pedagogia. Tradução de Dirceu Accioly Lindoso e Rosa Maria Ribeiro da Silva. 10. ed. Rio de Janeiro: Forense Universitária, v. 4, 2017.

TAILLE, Y. D. L. Piaget, Vigtsky, Wallon: Teorias psicogenéticas em discussão. São Paulo: summus, 1992

TREVISAN, R. NOVA ESCOLA. novaescola.org.br, 2018. Disponível em: $<$ https://novaescola.org.br/bncc/conteudo/58/o-que-sao-os-campos-de-experiencia-daeducacao-infantil>. Acesso em: 17 jan. 2019. 